\title{
Seasonal variation of plankton population of Borobila beel in Rangpur district
}

\author{
M.M.R.Chowdhury ${ }^{1}$, M.R.K.Mondol ${ }^{2} *$ and C. Sarker ${ }^{1}$ \\ ${ }^{1}$ Department of Fisheries Management, Bangladesh Agricultural University, Mymensingh-2202, Bangladesh \\ ${ }^{2}$ Department of Fisheries, University of Rajshahi, Rajshahi-6205, Bangladesh
}

\begin{abstract}
Seasonal variation of the plankton populations with some water quality parameters of Borobila beel, Rangpur district was carried out during July 2003 to June 2004. Total plankton ranged from $98.3 \times 104$ to $35.0 \times 105$ cells/l with mean values of $19.67 \pm 9.77 \times 105$ cells/l. A total of 51 genera of planktons were recorded belonging to Chlorophyceae, Bacillariophyceae, Cyanophyceae, Euglenophyceae, Dinophyceae, Crustacea and Rotifera. Among the phytoplankton, Euglenophyceae was the most dominant group and contributing 33\% of total phytoplankton in Borobila beel. The greatest abundance of phytoplankton was recorded in November with an average number $28.83 \times 105$ cells/l. The minimum abundance of phytoplankton was recorded in January $(61.7 \times 104$ cells/l). Among the zooplanktons Crustacea was dominant, contributing $71 \%$ of the total zooplankton population. The abundance of zooplankton showed two peaks of which one in the month of August (81.7x 104 cells/l) and another in the month of May (16.7 x104 cells/l). Phytoplankton and zooplankton have a nominal positive relationship. Zooplankton was less increased with the increasing of phytoplankton.
\end{abstract}

Key words: Water quality parameters, plankton population, Borobila beel.

\section{Introduction}

The beel/maun/jheel/tal/pat represents the transitional phase between the terrestrial and aquatic systems with water table at or near the surface or the land is covered with shallow depth of water. Soil and water of beels are very productive and good natural habitats of large and small indigenous fishes of different food habits. Many other fish and prawn species move into the inundated areas of beels from adjacent rivers and canal for breeding, grazing and nursing purpose during monsoon months (Jha, 1989). The qualitative and quantitative abundance of plankton and its relation to environmental condition has become a prerequisite for fish production. In most cases, the proliferation of planktonic algae is beneficial for aquaculture, fish production and wild fisheries operations. However, in some situations algal blooms can have a negative effect, causing severe economic losses to aquaculture, fisheries operations and having major environmental and human health impacts. So, the monitoring programmes of plankton are very important because they may provide information on possible new introductions and may serve as early warning systems to detect the onset of potentially hazardous blooms and may suggest predicative factors for blooms. Species diversity indices when correlated with physical and chemical parameters, provide one of the best ways to detect and evaluate the impact of pollution on aquatic communities (Maraglef, 1968). Due to absence of planktonic study in the Borobila beel, the present study was undertaken to study monthly variation of plankton population with some water quality parameters and to find out the scope of aquaculture in this beel, Rangpur.

\section{Materials and methods}

Location

Information on the selected beel was obtained from baseline survey report by ARDMCS (2003) that Borobila beel is located at Pirganj Upazila under Rangpur district. It is a semi-closed beel connected with other beels and rivers through bamboo screens and sluice gate. The beel has two distinct parts: the relatively larger part at southern side is known as boro (big) beel and the smaller part in northern side is called choto (small) beel. The beel has two inlets and one main outlet, of which one inlet is connected with the Akhira River that has a sluice gate to control the water flow, and another is connected with a beel called Angrar beel. The main outlet is at the southern part of the beel which is connected to Kuchiamari River. The range of basin depth is $1.83-3.35 \mathrm{~m}$.

Procedure of study

Plankton and water samples were collected monthly from July 2003 to June 2004 from six different sites of the beel. Samplings were made between 9.00 to 11.30 am. Ten liters of water were collected from each site by a plastic bucket and kept on wooden boat. Water temperature, $\mathrm{pH}$ and conductivity were measured directly from the collected water using a digital water proof $\mathrm{pH}, \mathrm{EC} / \mathrm{TDS}$ and temperature meters (HANNA instruments, model: HI 98129- HI 98130). Hundred ml sample of the collected water of each site were taken in a bottle and $\mathrm{NO}_{3}-\mathrm{N}$ were measured directly from the reading of spectrophotometer $\mathrm{HACH}$ water analysis 
Kit (HANNA instrument, model HI 93728) with one packet of HI 93728 reagent for $10 \mathrm{ml}$ filtered water samples. The concentration of $\mathrm{PO}_{4}-\mathrm{P}$ was measured directly from the reading of spectrophotometer $\mathrm{HACH}$ water analysis Kit (HANNA instrument, model HI 93713) with one packet of HI 93713 reagent for $10 \mathrm{ml}$ filtered water samples.

For study of plankton, the collected $10 \mathrm{~L}$ water was filtered through plankton net of 10, 30 and $55 \mu$ mesh and finally concentrated to $20 \mathrm{ml}$. The filtrates were then immediately preserved in $5 \%$ buffered formalin for further studies. Microscopic identification up to genera level was performed following the standard manual. Each sample was stirred well just before microscopic examination. One $\mathrm{ml}$ of stirred sample was transferred to Sedgewick-Rafter (S-R cell) cell with a wide mouth pipette. Identification and enumeration were done by a compound electrical microscope (NOVA $950 \mathrm{ES}$ ). All the planktons present in 20 squares of the cell chosen randomly were counted. The mean of three estimates was then calculated for each component occurring in the total count. Finally the quantitative counts of phytoplankton were done according to Rahman (1992) and expressed in cells/l. Qualitative studies were done after Peenak (1953), Ward and Whipple (1954), Needham and Needham (1962), Prescott (1964), Bellinger (1992) and APHA (1992).

\section{Results}

Environmental parameters

In the present study, temperature ranged from $18.5^{\circ} \mathrm{C}$ in December to $33.72^{\circ} \mathrm{C}$ in August, with a mean of $28.27 \pm 5.62^{\circ} \mathrm{C}$ showing a typical seasonal pattern (Fig. 1). $\mathrm{pH}$ of water varied between 7.12 and 8.68 (mean $8 \pm 0.51$ ) with the maximum in February and minimum in June. Total alkalinity of water ranged from 48.50 to 133.0 $\mathrm{mg} / \mathrm{l}$ with an mean value of $86.03 \pm 30.25 \mathrm{mg} / \mathrm{l}$. The maximum conductivity $(239.0 \mu \mathrm{s} / \mathrm{cm})$ was recorded in April and the minimum $(124.0 \mu \mathrm{s} / \mathrm{cm})$ in July with a mean value of $179.05 \pm 40.09 \mu \mathrm{s} / \mathrm{cm}$.

Nutrients

During the study period, $\mathrm{NO}_{3}-\mathrm{N}$ concentration fluctuated widely from 1.52 to $2.97 \mathrm{mg} / \mathrm{l}$ (mean value $2.31 \pm 0.52 \mathrm{mg} / \mathrm{l}$ ). The highest value was recorded in September and lowest in February (Fig. 2). Fluctuation of $\mathrm{PO}_{4}-\mathrm{P}$ concentration ranged from 0.08 to $0.88 \mathrm{mg} / \mathrm{l}$ (mean $0.29 \pm 0.23 \mathrm{mg} / \mathrm{l}$ ) with the maximum in April and minimum in October (Fig. 3).

Phytoplankton

Temporal abundance of total phytoplankton varied from $6.17 \times 10^{3}$ to $28.83 \times 10^{5}$ cells/l with an average mean value of $15.04 \pm 8.49 \times 10^{5}$ cells/l. Phytoplankton population showed peak abundance in November and lowest in January (Fig. 4). A total number of 40 phytoplankton genera belonged to five major groups-
Euglenophyceae, Chlorophyceae, Bacillariophyceae, Cyanophyceae and Dinophyceae were identified (Table 1). Among them, Euglenophyceae was the most dominant group and the Dinophyceae is least. Percent composition of these groups is shown in Figure 5.

Euglenophyceae

Euglenophyceae was the most dominant group of phytoplankton in respect to abundance with mean value $50.1 \pm 31.7 \times 10^{4}$ cells/l. This group was the most abundant in November $\left(13.33 \times 10^{5}\right.$ cells/l) and least in December-January $\left(13.3 \times 10^{4}\right.$ cells/l). The frequently occurring taxa of Euglenophyceae were Euglena, Tracelomonus, and Phacus.

Chlorophyceae

Chlorophyceae ranked as the second highest among phytoplankton groups in respect to abundance and first in number of genera (18). The range of Chlorophyceae numbers was from $83 \times 10^{3}$ to $10.50 \times 10^{5}$ cells/l with an average mean $47.8 \pm 34.2 \times 10^{4}$ cells/l. The occurrence of Chlorophyceae was highest in October and lowest in April. Chlorella, Staurastrum, Ulothrix, Pediastrum, Closterium, Cosmarium, Tetraedron etc. were predominant genera.

Bacillariophyceae

A total of 8 genera of Bacillariophyceae were observed in Borobila beel. Among these, Cyclotella, Navicula, Surirella, Pinnularia, Gyrosigma were predominant. Bacillariophyceae was the most dominant in November $\left(86.7 \times 10^{4}\right.$ cells/l) and lowest in March $\left(50 \times 10^{3}\right.$ cells/l). Cyanophyceae

The abundance of Cyanophyceae was found to be highest in September $\left(43.3 \times 10^{4}\right.$ cells/l) and lowest in December-January $\left(50 \times 10^{3}\right.$ cells/l) with 10 numbers of genera. Among them, Anabaena, Microcystis, Gomphospheria, Oscillatoria, Chroococcus, Aphanocapsa, Aphanizomenon were predominant.

Dinophyceae

Dinophyceae was the least dominant group of phytoplankton in respect of both abundance and number of species. Dinophyceae was the most abundant in November $\left(25.0 \times 10^{4}\right.$ cells/ $\left./\right)$. This group was rarely found in this beel from January to April. Only one genera Ceratium was found in this beel.

Zooplankton population

In the present study, the zooplankton populations of Borobila beel were composed of two major groups: Crustacean and Rotifer. Zooplanktons were represented by 11 genera among which 6 belonged to Crustacea and 5 to Rotifera. Total zooplankton populations ranged from $16.7 \times 10^{4}$ to $81.7 \times 10^{4}$ cells/l with a mean $46.3 \pm 21.5 \times 10^{4}$ cells/l. Monthly variations in mean abundance of Crustacea and Rotifera in Borobila beel are shown in Fig. 6. During the study period, Crustacea was the most dominant group composing $71 \%$ of the 
total zooplankton population and the rest were Rotifers. Total zooplankton populations showed two peaks. The maximum abundance of total zooplankton was recorded in the month of August $\left(75.0 \times 10^{4}\right.$ cells/l) and another in the month of May $\left(81.7 \times 10^{4}\right.$ cells/l).

\section{Crustacea}

Among crustaceans, Bosmina, Cyclops, Daphnia, Diaphanosoma, Diaptomus, Moina were predominant. Average abundance of Crustacea ranged from $33 \times 10^{3}$ to $50.0 \times 10^{4}$ cells/ 1 with a mean value $32.8 \pm 15.5 \times 10^{4}$ cells/l. Crustaceans are most abundant in October and least in July.

Rotifera

Among rotifers, Asplanchna, Brachionus, Filinia, Keratella, Polyarthra are predominant. The abundance of rotifers was the highest in August. Average abundance of Rotifera ranged from 0 to $35.0 \times 10^{4}$ cell/l with a mean value $13.5 \pm 12.8 \times 10^{4}$ cells/l. This group was rarely found in this beel from January to March.

\section{Discussion}

It is almost well established that the planktons can be an index to compare the relative productivity and fishery potential of different water bodies. They play an important role in the food chain of fishes. The results of seasonal variation in plankton population suggest that the favourable period for primary production is from August to November, when nutrient accumulation from freshwater run-off due to monsoon rainfall is higher. Singh (1960) in his study on the phytoplankton of inland water of Uttar Pradesh in India recorded primary peak of phytoplankton in the months of September-October. Razzaque et al. (1995) and Ehshan et al. (2000) also observed similar phenomenon in October in Halti beel and Chanda beel, respectively. The lowest abundance of phytoplankton was obtained in the month of January. Similarly Razzaque et al. (1995) and Ehshan et al. (2000) observed lowest abundance of phytoplankton in April and March in Halti beel and Chanda beel, respectively. A total of 40 genera of phytoplankton was identified in studied beel that were more or less similar to findings reported by Ehshan et al. (2000) who observed 44 genera of phytoplankton in Chanda beel. Razzaque et al. (1995) identified 87 genera of phytoplankton in Halti beel, and Saha and Hossain (2002) found 46 genera in Saldu beel.

It is well-established that the productivity of plankton depends on the ecological balance between the various physico-chemical factors. Phytoplankton abundance and taxonomic diversity depend upon the supply of nutrients in natural waters. In the present study, the highest phytoplankton density and species diversity was found in September to November, when the temperature and $\mathrm{N}-\mathrm{NO}_{3}$ concentration were found to be highest. Similar relationship also present in case of lower abundance of phytoplankton in low temperature and $\mathrm{N}-\mathrm{NO}_{3}$ concentration. Phosphate exhibited inverse relation with the growth rate of planktonic organisms indicating its consumption by the plankters to certain extent. The lower value of phosphate corresponded with the higher plankton abundance in AugustNovember supported this fact. Patra and Azadi (1987) found similar relationship between $\mathrm{P}_{-} \mathrm{PO}_{4}$ and plankton population.

In the present study, the range of total zooplankton populations was from $16.7 \times 10^{3}$ to $81.7 \times 10^{4}$ cells/l, with mean value of $46.3 \pm 21.5 \times 10^{4}$ cells/l which was more or less close to the values reported by Patra and Azadi (1987) in Halda River, Razzaque et al. (1995) in Halti beel and Ahmed et al (2004) in Shakla beel. Crustacea was dominant group and Rotifera was the rarest among zooplankton. Similarly Patra and Azadi (1987) reported that crustacea was the most dominant group in Halda River and Saha and Hossain (2002) also reported similar results in Saldu beel. Zooplankton showed two peaks, one in the month of August to October and another in the month of May which was similar to the observation reported by Das and Srivastava (1956) in a pond. Patra and Azadi (1987) found two peaks of zooplankton one in August and another in February and Razzaque et al. (1995) reported that the zooplankton showed two peaks, one in May and another in October in Halti beel. Both phytoplankton and zooplankton showed direct relationship between themselves (Fig. 7). Similar relationships were also reported by Patra and Azadi (1987) in Halda River, Ali et al. (1985) in a pond, and Razzaque et al. (1995) in Halti beel. However, Das and Srivastava (1956) observed inverse correlation between phytoplankton and zooplankton.

Among the vast inland fishery resources, beels are more potential. But fish production from beel fishery is decreasing day by day due to various man made activities. So, beel fishery should be preserved for augmenting fish production and ecological balance of this habitat. Therefore, restoration and development of degraded habitats and rehabilitation of depleted stocks by ranching programme are urgently needed. From the present study, it is suggested that further study on seasonal changes of phytoplankton in relation to some water quality parameters should be under taken in different sites of Borobila beel.

\section{Acknowledgments}

The author is immensely grateful to Aquatic Research Development Management and Conservation Study (ARDMCS) funded by World Bank for its financial and technical supports in performance of this research work. The Authors are indebted to Professor Dr. Somen Dewan, Department of Fisheries Management, Bangladesh Agricultural University, Mymensingh for his co-operation and advice during the study period. 
Table 1. Generic status of plankton with their different groups recorded from Borobila beel during the study period

\begin{tabular}{|c|c|c|}
\hline \multicolumn{2}{|c|}{ Phytoplankton } & Zooplankton \\
\hline Euglenophyceae & Bacillariophyceae & Crustacea \\
\hline Euglena & Amphora & Cyclops \\
\hline Phacus & Cyclotella & Daphnia \\
\hline Tracelomonus & Cymbella & Diaphanosoma \\
\hline Strombomonas & Eunotia & Diaptomus \\
\hline & Navicula & Moina \\
\hline Chlorophyceae & Pinnularia & Nauplius \\
\hline Ankistrodesmus & Stauroneis & \\
\hline Arthrodesmus & Surrirella & Rotifera \\
\hline Chlorella & & Asplanchna \\
\hline Closteriopsis & Cyanophyceae & Brachionus \\
\hline Closterium & Anabaena & Filinia \\
\hline Coenochloris & Aphanocapsa & Keratella \\
\hline Cosmarium & Chroococcus & Polyarthra \\
\hline Euastrum & Coelospherium & \\
\hline Microspora & Gloeocapsa & \\
\hline Pediastrum & Gomphospheria & \\
\hline Radiococcus & Merismopedia & \\
\hline Scenedesmus & Oscillatoria & \\
\hline Spirogyra & Phormidium & \\
\hline Staurastrum & Polycystis & \\
\hline Tetraedron & & \\
\hline Trebouxia & Dinophyceae & \\
\hline Ulothrix & Ceratium & \\
\hline Xanthidium & & \\
\hline
\end{tabular}

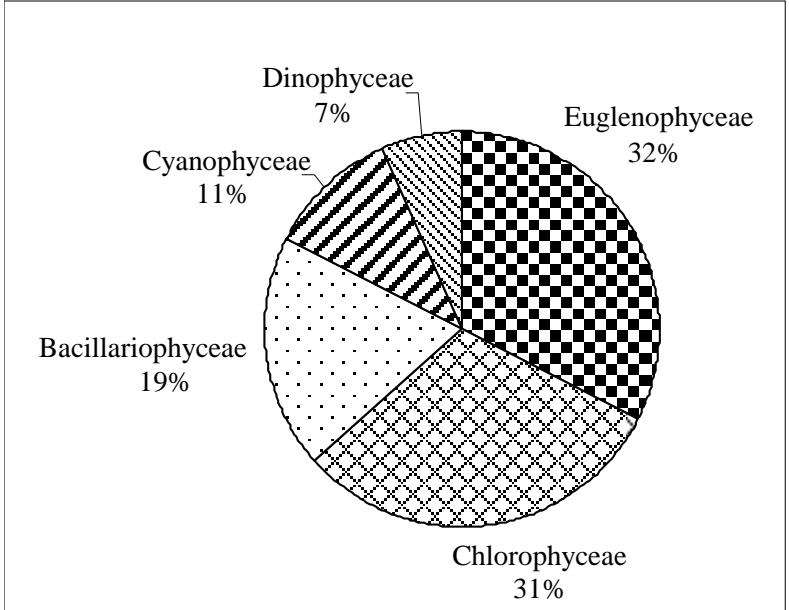

Fig. 5. Percent composition of various phytoplakton groups (average mean of one year)

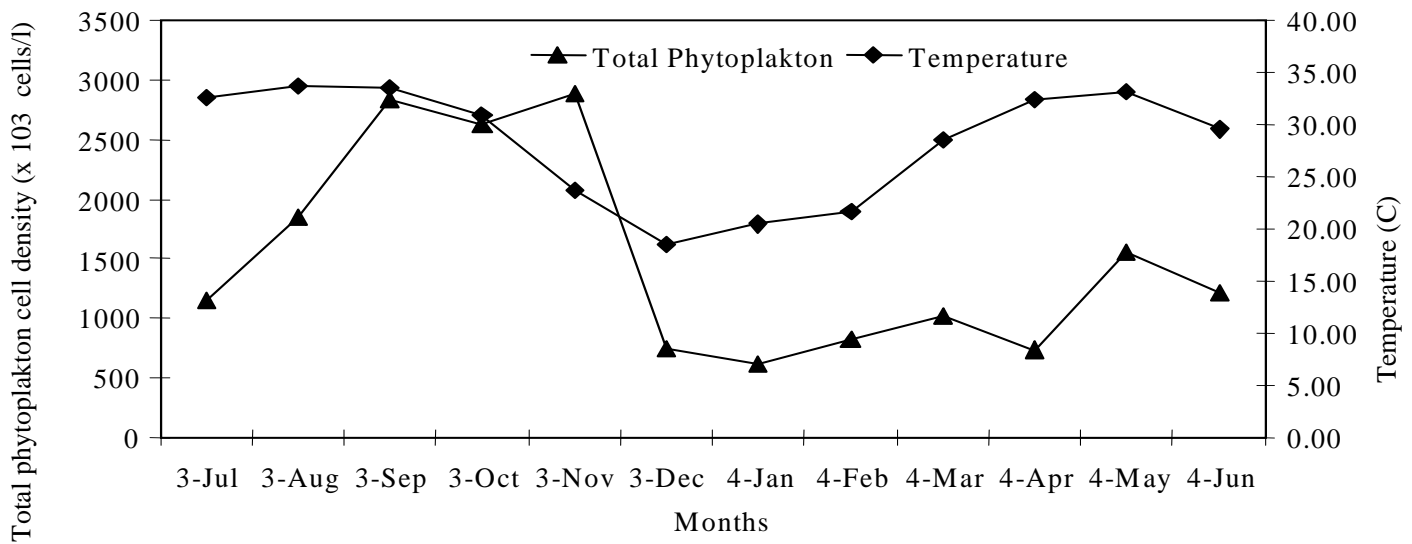

Fig. 1. Effects of temperatures on the seasonal abundance of plankton population in Borobila beel during the study period

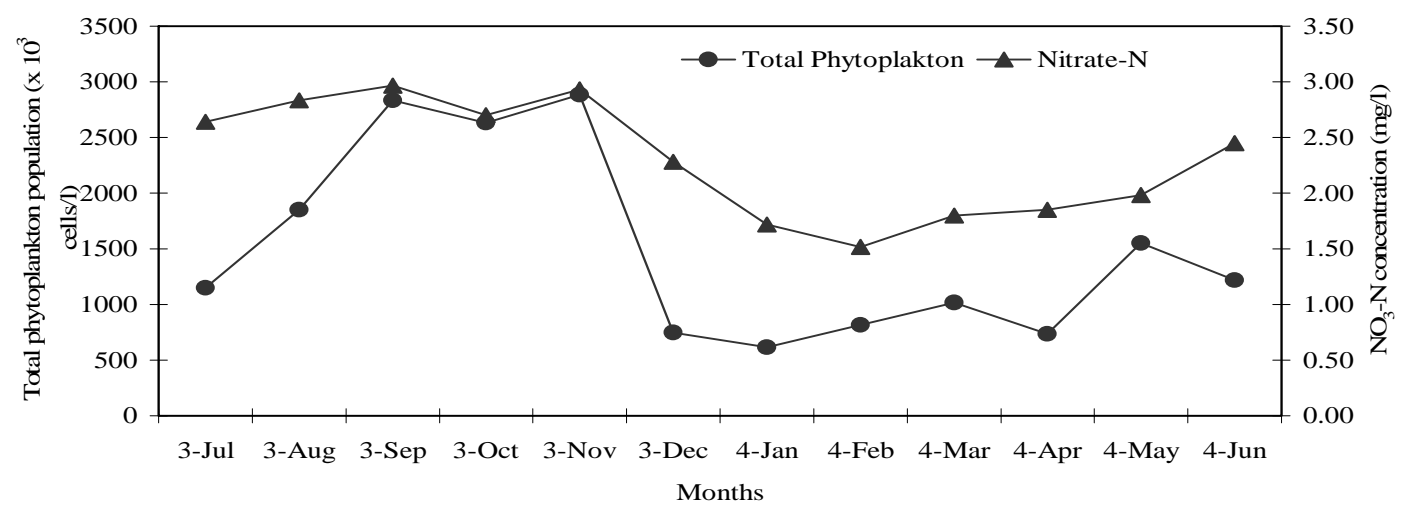

Fig. 2. Effects of Nitrate-N concentrations on the seasonal abundance of total phytoplankton population in Borobila beel during the study period 


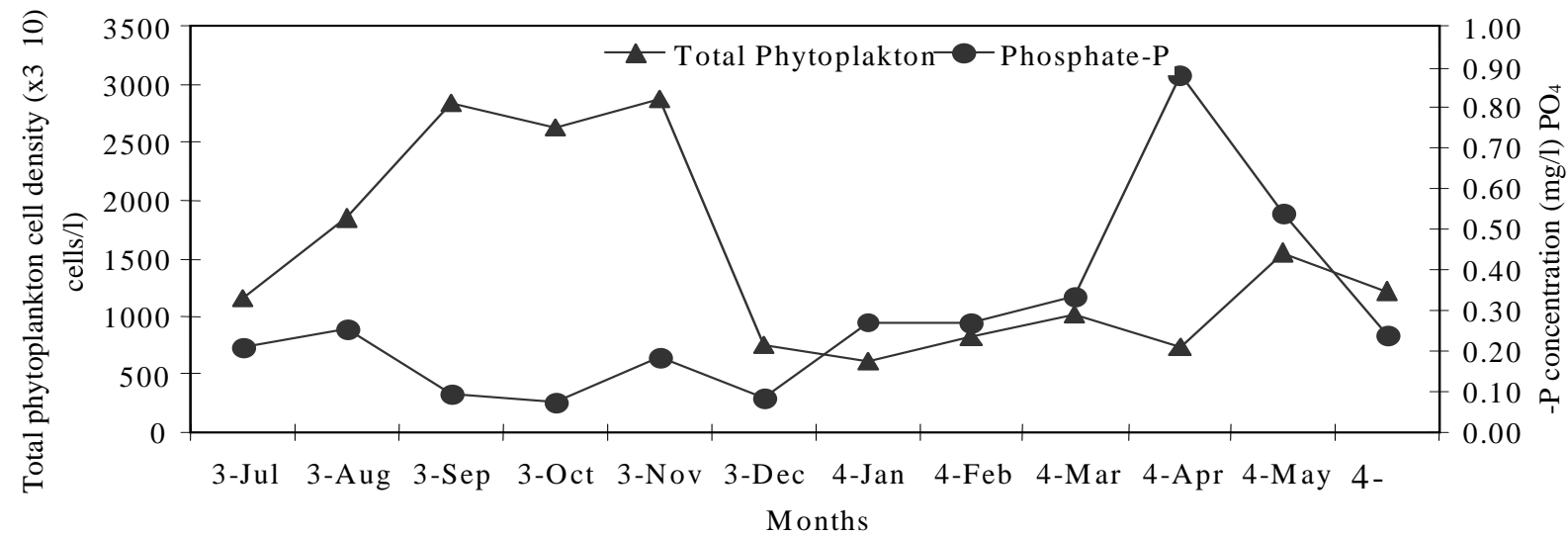

Fig. 3. Effects of Phosphate-P concentrations on the seasonal abundance of total phytoplankton population in Borobila beel during the study

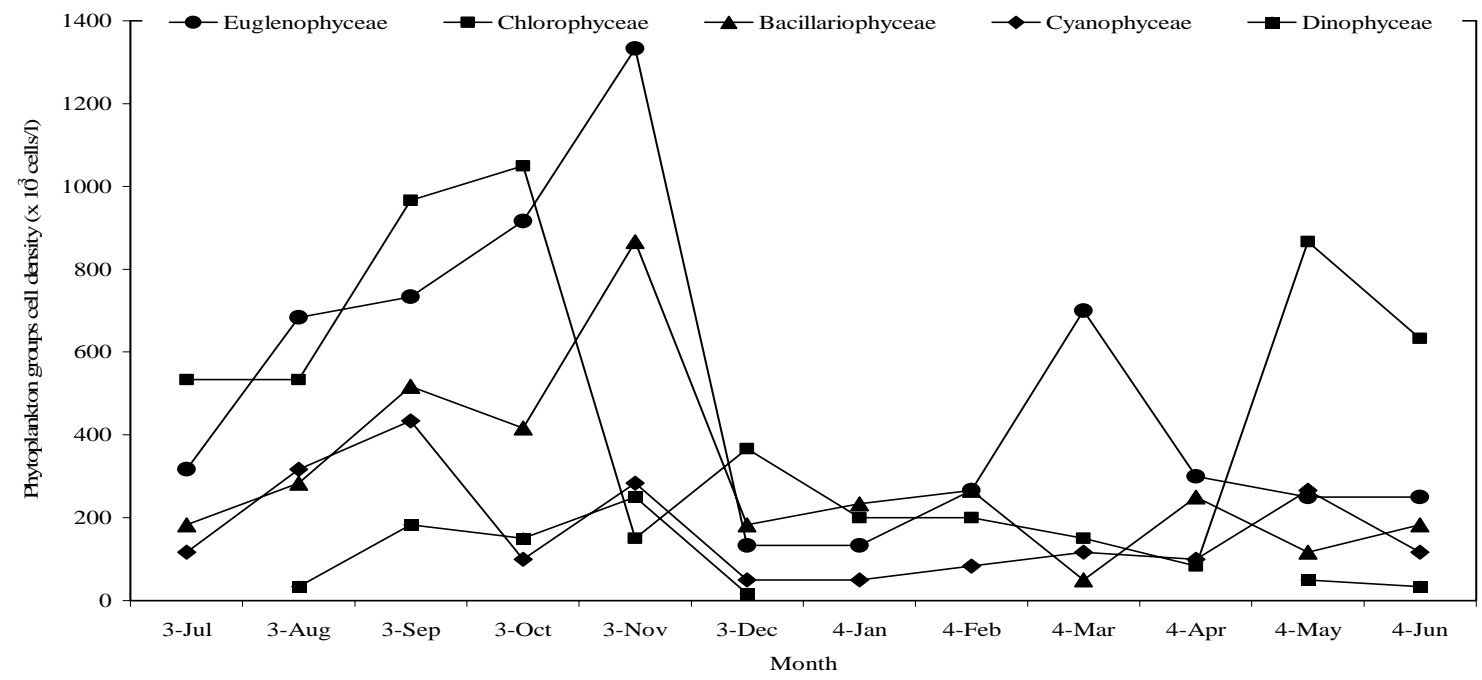

Fig. 4: Seasonal fluctuation of different planktonic groups in Borobila beel during the study period

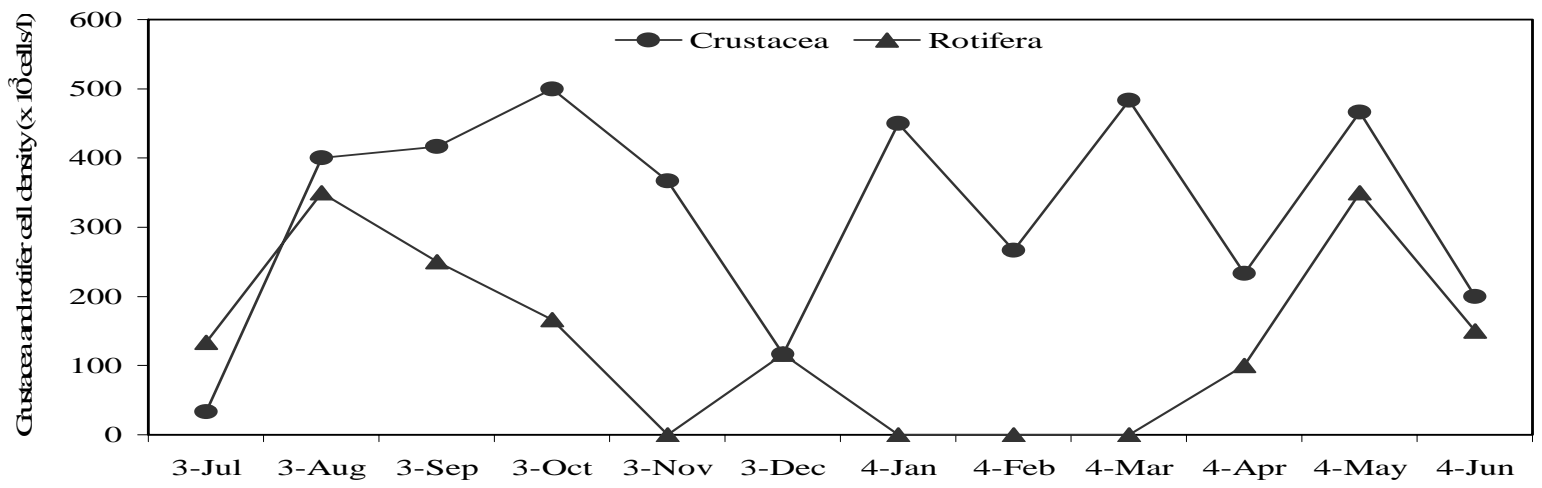

Months

Fig. 6. Seasonal fluctuation of Crustacea and Rotifer in Borobila beel during the study period 


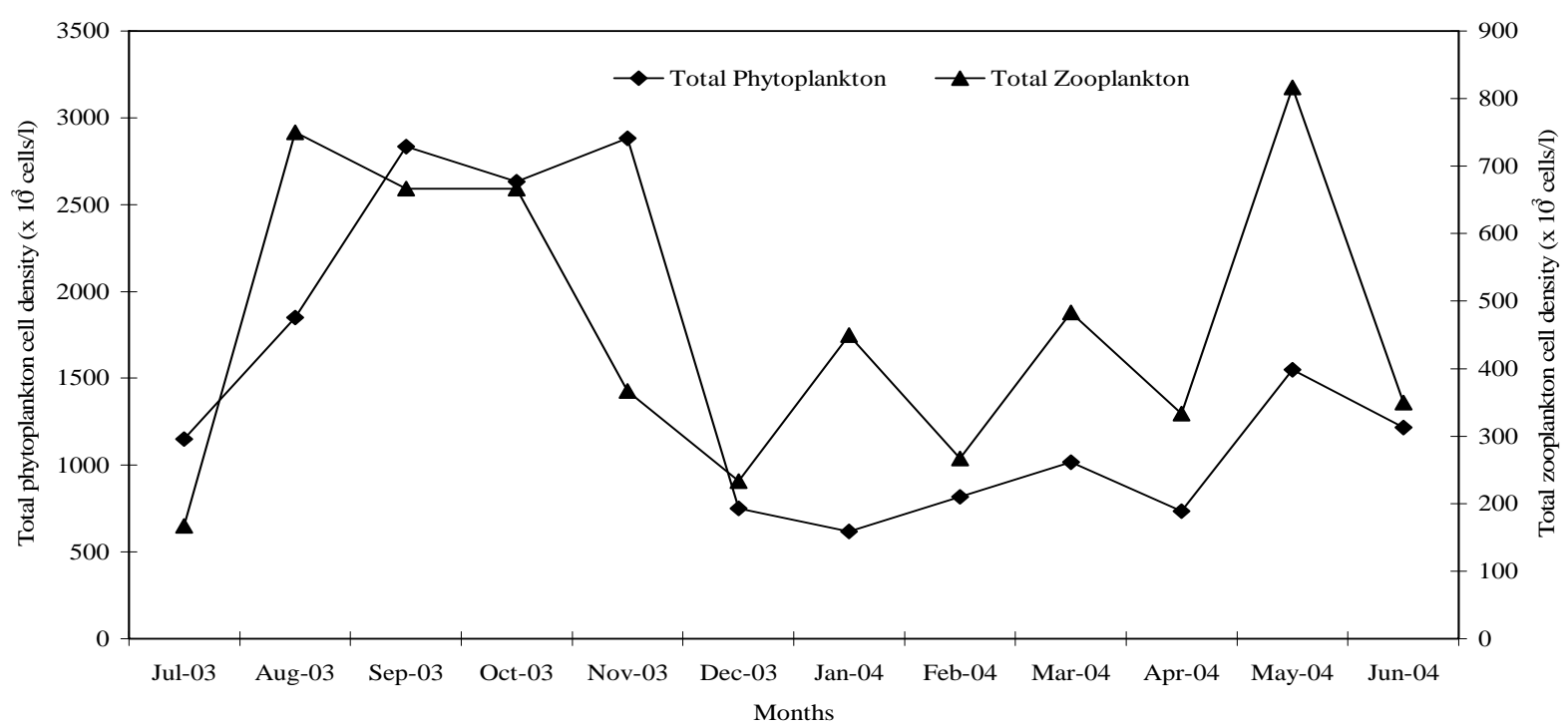

Fig. 7. Temporal relationship between total phytoplankton and total zooplankton population of Borobila beel during the study period

\section{References}

Ahmed, K.K.U, Hasan, K.R., Ahamed, S.U. and Mustafa, G. 2004. Ecology of Shakla beel (Brahmanbaria), Bangladesh. Bangladesh J. Fish. Res. 8(2): 101-111.

Ali, M.M., M.A. Islam and M.A.B. Habib. 1985. Monthly abundance of zooplankton and correlation of various dominant species and nauplius of zooplankton with some water characters in a pond. Univ. J. Zool. Rajshahi Univ. 4: 42-49.

APHA. 1992. Standard methods for the examinations of water and waste water. American Public Health Association, 1015 Eighteenth Street, New York, Washington D. C., 20035, 874 pp.

ARDMCS. 2003. Baseline information of five beels/ floodplains/rivers under aquatic biodiversity assessment study. ARDMCS, Fourth Fisheries Project (FFP), DoF, GOB/GEF/Worldbank, Dhaka, Bangladesh, $30 \mathrm{pp}$.

Bellinger, E.G. 1992. A key to common algae: Freshwater, estuarine and some coastal species. The Institute of Water and Environment Management, London, UK.

Das, S.A. and Srivastava, V.K. 1956. Quantitative on freshwater plankton of a fish tank in Lucknow, India. Proc. Nat. Acad. Soc. India 26: 85-91.

Ehshan, M.A., Hossain, M.S. Razzaque, A. and Alam, M.S. 2000. Kua-an unusual but important fishery of Chanda beel. Bangladesh J. Zool. 28(1): 69-74.

Jha, B.C. 1989. Classification, Management and Status of fish production in beels. Inland Fisheries Society of India. CIFRI, Barrackpore, India, pp. 52-60.
Maraglef, R. 1968. Perspectives in ecological theory. University of Chicago Press. Chicago, 111 pp.

Needham, J.G. and Needham. P.R. 1962. A guide to the study of freshwater biology. $5^{\text {th }}$ edn. Liolden-day, Inc., San Francisco, 106 pp.

Patra, R.W.R. and Azadi, M.A. 1987. Ecological studies on the planktonic organisms of the Halda River. Bangladesh J. Zool. 15(2): 109-123.

Peenak, R.W. 1953. Freshwater invertebrate of the United States. Ronald Press, New York, 679 pp.

Prescott, G.W. 1964. Algae of the western Great lakes area. Wm. C. Brown. Co., Inc. Dubyque. Iowa., 946 pp.

Rahman, M.S. 1992. Water quality management in aquaculture. BRAC Prokashana, Dhaka, pp 83-84.

Razzaque, A., Hossain, M.S., Islam, A.K.M.S., Hossain, M.M.M. and Ehshan, M.A. 1995. Study on plankton population of Halti beel at Natore, Bangladesh. Bangladesh J. Aquaculture, 17: 19-23.

Saha, B.K. and M.A. Hossain. 2002. Soldu beel fishery of Tangail. Bangladesh J. Zool. 30(20): 187-194.

Singh, V.P. 1960. Phytoplankton ecology of the inland waters of Utter Pradesh. Proc. Symp. Algal. ICAR, New Delhi, pp. 243-271.

Ward, H.B. and Whipple, G.C. 1954. Freshwater Biology. John Willey and Sons Inc., New York, 128 pp.

Manuscript received on 06.08.07, accepted on 29.08.07 